\title{
The synthesis of lysine by the lactating goat
}

\author{
By D. C. EDWARDS* AND R. A. DARROCH \\ Hannah Dairy Research Institute, Kirkhill, Ayr \\ (Received 22 November 1955-Revised 2 May 1956)
}

In planning the present experiment it was assumed that, if the diet of a lactating ruminant is devoid of lysine and the animal is in positive nitrogen balance, the lysine in the milk must have been synthesized in the animal by the micro-organisms in its paunch. Lysine synthesis by rumen bacteria has been demonstrated by McDonald (1944) and by McNaught (I95 I). The former fed sheep on a diet in which zein represented $82 \%$ of the total protein and it was estimated that $40 \%$ of the zein was converted into lysine-containing microbial protein. McNaught's experiments showed a $12 \%$ increase in the lysine content of bacterial preparations from the rumen, the material being incubated under conditions shown by Smith \& Baker (I944) to cause very little change in the facies of the rumen flora. It thus remained to be seen whether such a synthesis could provide an animal with sufficient lysine to allow the production of milk protein and to maintain the animal in good health.

Preliminary experiments (unpublished) carried out at this Institute were unsatisfactory because the beet pulp, used in the basal diet and fed as roughage, contained more lysine than had been originally thought. In addition, the microbiological assay used for lysine estimation gave results which, though reproducible, did not agree with the figures published by other authors. A new experiment was therefore devised with a diet much lower in lysine and a more reliable method for estimating lysine. This experiment is described in the present paper.

\section{EXPERIMENTAL}

Chemical methods. Lysine was estimated by the specific enzymic method described by Gale \& Epps (1944) and Gale (1945, 1948). The milk, food and faeces were hydrolysed under conditions recommended by Schram, Dustin, Moore \& Bigwood (I953) to minimize humin formation. A weighed sample of material was refluxed for $22 \mathrm{~h}$ with sufficient $6 \mathrm{~N}-\mathrm{HCl}$ to give a final concentration of $\mathrm{r} \%$ dry matter in the mixture. The hydrolysate was distilled to dryness under reduced pressure, water was added and the distillation repeated. The residue was dissolved as far as possible in water, filtered to remove humin, neutralized with strong $\mathrm{KOH}$ solution and made up to $25 \mathrm{ml}$. Three $4 \mathrm{ml}$. samples were pipetted into double side-arm Warburg flasks, I ml. 0.2 M-phosphate buffer, $\mathrm{pH} 6$, was added and the lysine determined by means of lysine decarboxylase.

Nitrogen was estimated by the Kjeldahl method with selenium as catalyst. The

* Present address: Wellcome Research Laboratories, Beckenham, Kent. 
amount of fat in the milk was determined by the Gerber method and total solids by evaporation to dryness at $100^{\circ}$.

Preparation of the experimental diets. In view of the use of cellulose in Scandinavia, during the 1939-45 war, for feeding to cattle, it was decided to use some form of readily digestible fibre in place of the beet pulp used in the first (unpublished) trial. Partly processed paper pulp was at first thought to be suitable but could not be obtained free from hypochlorite. Alkali-treated straw as the sole roughage was known to be acceptable to ruminants (Mendel, I92I) and it was therefore chosen as a source of fibre poor in lysine. It was prepared by steeping oat straw for $24 \mathrm{~h}$ in $10 \%(\mathrm{w} / \mathrm{v}) \mathrm{NaOH}$ in an iron vessel of roo gal. capacity. At the end of this time the straw was turned and left to soak for a further $24 \mathrm{~h}$. The treated straw was then placed on top of the end of a hose at the bottom of a galvanized iron bin and was washed by allowing tap water to pass upwards through it. Twenty-four hours later, by which time the washings were neutral, the straw was placed on a tripod to drain and was finally dried in an oven with a forced draught of hot air. The dried straw was chopped and used for roughage in this form. For mixing into the production ration, it was put through a hammer mill from which it emerged in a form resembling cotton-wool. Urea and treacle (and in the control diet lysine also) were dissolved in water and mixed with the main part of the diet as recommended by Owen, Smith \& Wright (I943). The salt mixture was added next, followed by starch and zein. Mixing was continued till the brown colour of the molasses appeared to be uniformly dispersed. At this stage the diet was in the form of a slightly damp light-brown powder. Finally this powder was mixed with the milled alkali-treated straw, and the whole was passed through a hammer mill to complete the mixing. The experimental diet thus mixed contained zein $17 \cdot 4$, treated straw 34.7 , potato starch 34.7 , treacle 8.7 , urea 0.5 and salt mixture $4.0 \%$ by weight. The diet given to goat no. 3 contained, in addition, 0.2 parts by weight of lysine monohydrochloride dihydrate. The salt mixture was that of Hubbell, Mendel \& Wakeman (1937) with zinc and cobalt added. Its composition was: $\mathrm{CaCO}_{3}$ 1357.5, KI 0.20 , $\mathrm{MgCO}_{3} 62.5, \mathrm{MnSO}_{4} \cdot 4 \mathrm{H}_{2} \mathrm{O} 0.88, \mathrm{MgSO}_{4} \cdot 7 \mathrm{H}_{2} \mathrm{O} 40 \cdot 0, \mathrm{NaF} 2.50, \mathrm{NaCl}$ 172.5, $\mathrm{KAl}\left(\mathrm{SO}_{4}\right)_{2}$. I2 $\mathrm{H}_{2} \mathrm{O} 0 \cdot 43, \mathrm{KCl} 280 \cdot 0, \mathrm{CuSO}_{4} \cdot{ }_{5} \mathrm{H}_{2} \mathrm{O} 2 \cdot 25, \mathrm{KH}_{2} \mathrm{PO}_{4} 53^{\circ} \cdot 0, \mathrm{ZnSO}_{4} \cdot 7 \mathrm{H}_{2} \mathrm{O}$ $2 \cdot 25, \mathrm{FePO}_{4} \cdot 4 \mathrm{H}_{2} \mathrm{O} 5 \mathrm{I} \cdot 3$, and $\mathrm{CoSO}_{4} 0 \cdot 25 \mathrm{~g}$.

Animals. The animals used were three British Saanen goats. Goats nos. I and 2 (given the low-lysine diet) were 2 years old and weighed 54 and $56 \mathrm{~kg}$ respectively. This was their first lactation. The control animal was 3 years old, weighed $65 \mathrm{~kg}$, and this was its second lactation.

Management of animals and collection of samples. The experiment was divided into three periods. In period $\mathrm{I}$, a mixture consisting of bruised oats 9 , bean meal 6 and dried grass 3 parts by weight, together with hay as roughage, was gradually replaced by the experimental diets over a period of 2 weeks. In period 3 the goats were changed abruptly back to the initial mixture of oats, beans, dried grass and hay. In period 2 the experimental diets were fed to two of the goats (nos. I and 2) and goat no. 3 received the experimental diet with the lysine supplement. Food was given in $500 \mathrm{~g}$ lots three times daily -at the morning milking, at noon and at the afternoon milking. With each of the three allowances of meal, $500 \mathrm{~g}$ of the specially prepared 
straw were given. This procedure continued for 12 days during which complete collections of milk, faeces and urine were made and representative samples taken.

The goats were confined in metabolism crates, which were so designed that the animals could be machine-milked in them. Urine and faeces both fell on to an inclined glass plate at the lower end of which, continuing in the same plane, was another plate of perforated metal. The perforations, which were $3.2 \mathrm{~mm}$ across, were much smaller in diameter than the average faecal pellet (IO-I $5 \mathrm{~mm}$ diameter). Below this perforated plate was a metal funnel leading to a bottle for the urine. At the far end of the perforated plate was a galvanized iron trough which caught the faeces as they rolled off the inclined rectangular plane formed by the glass plate and the perforated metal sheet. By this arrangement it was found possible to collect faeces and urine with minimal contamination of the one by the other. Milk, urine and faeces were sampled for analysis every 2 nd day.

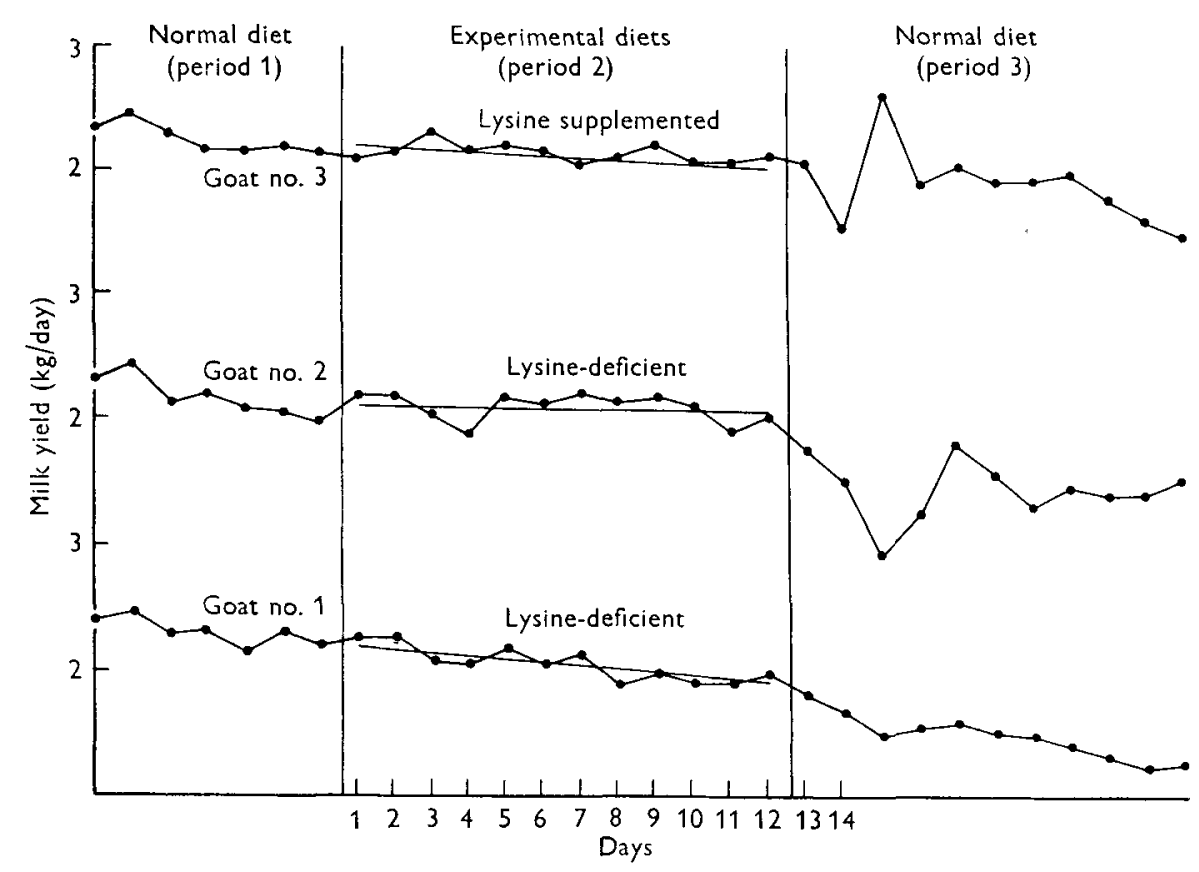

Fig. I. Milk yields of the goats. The straight lines are the regression lines of decline in milk yield.

\section{RESULTS}

The milk yields (Fig. I) show that there was no marked fall in yield when the goats were changed from their normal food mixture to the experimental one, whether this was free from lysine as with goats nos. I and 2 or contained lysine as with goat no. 3 . The regression lines show that the rates of decline of milk yields, while the experimental diets were being fed, were $3 \mathrm{I}$ and $5 \mathrm{~g}$ /day for goats nos. I and 2, compared with I $3 \mathrm{~g} /$ day for the control animal no. 3. Only at the beginning of period 3 , when there 
was a sudden change from the experimental to the normal diet, did the milk yields show gross changes. The change in diet had the marked and unexpected effect of causing loss of appetite in the animals, and consequently the milk yields suffered.

Table I shows the mean values for intakes of food, straw, nitrogen and lysine and for output of milk, urine, faeces, nitrogen and lysine. There were no refusals of the production ration, but during the experimental period the intake of the alkali-treated straw (roughage) tended to rise, probably because the period of introduction of the animals to the diet was too short.

Table $\mathrm{I}$. Mean daily (1) intakes and (2) excretions and balances of nitrogen and lysine of goats nos. I and 2 on the lysine-deficient diet and of goat no. 3 on the lysinesupplemented diet

\begin{tabular}{|c|c|c|c|c|c|c|c|c|}
\hline \multirow[b]{2}{*}{$\begin{array}{l}\text { Goat } \\
\text { no. }\end{array}$} & \multirow[b]{2}{*}{$\begin{array}{l}\text { Diet } \\
(\mathrm{g})\end{array}$} & \multirow[b]{2}{*}{$\begin{array}{l}\text { Straw } \\
(\mathrm{g})\end{array}$} & \multicolumn{3}{|c|}{ Nitrogen } & \multicolumn{3}{|c|}{ Lysine } \\
\hline & & & $\begin{array}{c}\text { From } \\
\text { diet } \\
(\mathrm{g})\end{array}$ & $\begin{array}{l}\text { From } \\
\text { straw } \\
\text { (g) }\end{array}$ & $\begin{array}{l}\text { Total }(A) \\
(\mathrm{g})\end{array}$ & $\begin{array}{c}\text { From } \\
\text { diet } \\
\text { (g) }\end{array}$ & $\begin{array}{c}\text { From } \\
\text { straw } \\
(\mathrm{g})\end{array}$ & $\begin{array}{c}\text { Total }(a) \\
(\mathrm{g})\end{array}$ \\
\hline $\mathrm{I}$ & 1500 & 866 & $45^{\circ} 0$ & $1 \cdot 7$ & $46 \cdot 7$ & $0.9 \mathrm{r}$ & 0.35 & $1 \cdot 26$ \\
\hline 2 & 1500 & 957 & $45^{\circ} \circ$ & $1 \cdot 9$ & $46 \cdot 9$ & 0.91 & 0.38 & $1 \cdot 29$ \\
\hline 3 & 1500 & 962 & $4^{6 \cdot 5}$ & $r \cdot 9$ & 48.4 & 4.95 & $0.3^{8}$ & $5 \cdot 33$ \\
\hline
\end{tabular}

(2) Excretions and balances

\begin{tabular}{|c|c|c|c|c|c|c|c|c|c|c|c|}
\hline \multirow[b]{2}{*}{$\begin{array}{c}\text { Goat } \\
\text { no. }\end{array}$} & \multirow[b]{2}{*}{$\begin{array}{c}\text { Milk } \\
(\mathrm{g})\end{array}$} & \multirow[b]{2}{*}{$\begin{array}{l}\text { Urine } \\
\text { (ml.) }\end{array}$} & \multirow[b]{2}{*}{$\begin{array}{c}\text { Faeces } \\
\text { (g) }\end{array}$} & \multicolumn{4}{|c|}{ Nitrogen } & \multicolumn{2}{|c|}{ Lysine } & \multirow[b]{2}{*}{$\begin{array}{c}\text { Nitrogen } \\
\text { balance } \\
(A-B) \\
(\mathrm{g})\end{array}$} & \multirow{2}{*}{$\begin{array}{c}\text { Lysine } \\
\text { balance } \\
(a-b) \\
(\mathrm{g})\end{array}$} \\
\hline & & & & $\begin{array}{l}\text { In } \\
\text { milk } \\
(\mathrm{g})\end{array}$ & $\begin{array}{c}\text { In } \\
\text { urine } \\
(\mathrm{g})\end{array}$ & $\begin{array}{l}\text { In } \\
\text { faeces } \\
(\mathrm{g})\end{array}$ & $\begin{array}{c}\text { Total } \\
(B) \\
(\mathrm{g})\end{array}$ & 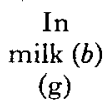 & $\begin{array}{c}\text { In } \\
\text { faeces } \\
\text { (g) }\end{array}$ & & \\
\hline I & 1998 & 569 & 2073 & 8.7 & $24 \cdot 4$ & $4 \cdot 2$ & $37 \cdot 3$ & $3 \cdot 4^{\circ}$ & $2 \cdot 75$ & +9.4 & $-2 \cdot 14$ \\
\hline 2 & 2031 & 812 & 2264 & 8.7 & $2 \pi \cdot$ & $6 \cdot 2$ & & & & +10.7 & $-2 \cdot 12$ \\
\hline 3 & 2083 & $106 \mathrm{I}$ & 2484 & $9 \cdot 2$ & $22 \cdot 4$ & $7 \cdot 6$ & $39 \cdot 2$ & $3 \cdot 82$ & $3 \cdot 22$ & $+9 \cdot 2$ & $+1 \cdot 51$ \\
\hline
\end{tabular}

Table $I$ shows also the nitrogen and lysine balances. The positive nature of the nitrogen balances is taken to indicate that the lysine in the milk was not coming from breakdown of tissue proteins. In calculating the lysine balances the lysine content of the faeces has been omitted since much of the lysine in the gut may not be available to the animal for the synthesis of milk protein. Further, the amount of lysine in the urine was so small that it was ignored. It is evident that sufficient synthesis of lysine took place in the animals to supply not only the amount by which the lysine in the milk exceeded that in the food but also the amount of lysine that must have been stored in the tissue proteins under conditions of positive nitrogen balance. The lysine in the milk of the animals on the lysine-deficient diets was therefore a minimal measure of the extent to which the goats were benefiting from microbial synthesis.

There was no evidence from analysis of fat and total solids that the milk had changed in composition or quality as a result of the experimental diets. The lysine-deficient animals maintained averages of 3.3 and $3.4 \%$ for milk fat and $\mathrm{II}_{1} \cdot 4$ and $\mathrm{I}_{2} \cdot \mathrm{I} \%$ for total milk solids which compared well with $3 \cdot 2 \%$ fat and I $_{1} \cdot 6 \%$ total milk solids for 
the control animal. The nitrogen content of the three milks which was around $0.45 \%$ compared not unfavourably with figures from the same herd obtained in previous years, and the milk may therefore be taken as being normal.

\section{DISCUSSION}

The results show that the synthesis of lysine in the goats was sufficient to maintain them in lactation and in positive nitrogen balance. The milk yield/goat (about $2 \mathrm{~kg} /$ day) was small, and there is no indication from the present experiment whether a higher milk yield could have been maintained on a similarly low intake of lysine. The evidence from the literature is, if anything, against such a possibility, for Morris \& Wright (1933 $a, b)$ suggested that lysine could be a limiting factor in the lactation of dairy cows giving over 4 gal. milk/day.

The very unusual diet successfully given in this experiment calls for some comment. It contained no added vitamins beyond traces present in the potato starch. Ruminants do not require dietary vitamin $\mathrm{C}$ and can synthesize a number of the B-complex vitamins in the rumen (Kon \& Porter, I947-8). Vitamin $\mathrm{K}$ may be formed in the rumen (McElroy \& Goss, I940), and Chanda, Clapham \& Owen (I955) have shown that the vitamin A reserves would not be likely to be depleted during the period of the present experiment. In respect of protein, the diet was not so deficient as the diet successfully fed to non-lactating ruminants by Loosli, Williams, Thomas, Ferris \& Maynard (I949) who kept three sheep and two goats in positive nitrogen balance for Io days on a diet which consisted of maize starch, maize sugar, Cellophane, lard, urea, minerals and vitamins $A$ and D. How far the three animals in the present experiment were dependent on microbial synthesis and on their own reserves for the various factors that were missing from the diet can only be a matter of conjecture. It can be said, however, that the animals' condition bore no resemblance to that of animals suffering dietary privation, for such a privation would certainly have caused a sudden drop in milk yield.

From Table I it can be calculated that, in the two goats that received no lysine, the lysine in the milk exceeded that in the food by $2 \cdot \mathrm{I} \mathrm{g} /$ day. The animals must therefore, with the aid of their rumen bacteria, have synthesized at least that amount daily. 'This value compares well with the estimates of about $2.3 \mathrm{~g}$ lysine/day synthesized in the rumens of goats and sheep on the protein-free diet used in the U.S.A. by Loosli $e$ t al. (1949), who calculated their result from the daily intake of nitrogen and the lysine content of the rumen. If the rumen protein in the present animals had had the same composition ( $5.7 \mathrm{I} \%$ lysine in rumen protein) as that of the animals of the American workers, the synthesis of protein in the rumen would have been $\frac{2 \cdot \mathrm{I}}{5 \cdot 7 \mathrm{I}} \times \frac{100}{\mathrm{I}}=37 \mathrm{~g}$ protein/day. Holmes, Moir \& Underwood (I953) found $6.2 \%$ of lysine nitrogen in the rumen-protein nitrogen of their 'dry-fed' sheep. If the rumen of the goats in the present experiment had contained material of the same composition as that in these 'dry-fed' sheep, the $2 \cdot 1 \mathrm{~g}$ lysine synthesized by the goats would correspond to $\frac{2 \cdot 1 \times 19.16 \times 100}{6.2 \times 16}=41$ g protein. In this calculation 19.16 is the percentage of nitrogen 
in lysine and it is assumed that the rumen protein contains $16 \%$ nitrogen. McNaught $\&$ Smith (1947-8) calculated that the amount of protein synthesized daily in the bovine rumen might possibly be 100-150 g, and Agrawala, Duncan \& Huffman (I953) found, by analysis of rumen contents within $6 \mathrm{~h}$ of feeding, that calves could synthesize from 35 to $109 \mathrm{~g}$ protein/day, when fed only once daily on a ration devoid of protein, urea being the sole nitrogen source.

Table 2. Comparison of rates of biosynthesis of lysine by ruminants

\begin{tabular}{|c|c|c|c|c|c|}
\hline Animals & $\begin{array}{c}\text { Source of } \\
\text { dietary protein }\end{array}$ & $\begin{array}{l}\text { Lysine } \\
\text { synthesis } \\
\text { (g/day) } \\
\text { (a) }\end{array}$ & $\begin{array}{c}\text { Body- } \\
\text { weight } \\
\text { (kg) } \\
\text { (b) }\end{array}$ & $\begin{array}{c}\text { Lysine } \\
\text { synthesis } \\
\text { (mg/kg } \\
\text { body- } \\
\text { weight/day) } \\
(a \div b \times 1000)\end{array}$ & Reference \\
\hline Milking goats & $\begin{array}{l}\text { Zein, urea, starch, sugar } \\
\text { and alkali-treated straw }\end{array}$ & $2 \cdot I$ & 35 & 60 & Present paper \\
\hline $\begin{array}{l}\text { Sheep and } \\
\text { goats }\end{array}$ & $\begin{array}{l}\text { Urea, starch, sugar and } \\
\text { Cellophane }\end{array}$ & $I \cdot 5^{*}$ & 35 & 43 & Loosli et al. (1949) \\
\hline Calves & $\begin{array}{l}\text { Urea, starch, sugar and } \\
\text { Cellophane }\end{array}$ & $9 \cdot 12 \dagger$ & 230 & 40 & Duncan et al. (1953) \\
\hline
\end{tabular}

Either of the estimates ( 37 or $4^{\mathrm{I}} \mathrm{g}$ ) of protein synthesized daily in the present experiment must represent a considerable contribution to the animal's requirement and may be compared with those found by Loosli et al. (1949) and Agrawala et al. (1953) by using the amino-acid analyses given by Duncan, Agrawala, Huffman \& Luecke (1953). This comparison (Table 2) shows that the rate of synthesis of lysine may have been somewhat faster in the lactating goats than in either of the two other groups of animals. Taken collectively the results indicate the extent to which the ruminant may benefit from microbial synthesis of protein.

\section{SUMMARY}

I. A lysine-deficient diet consisting of zein, urea, potato starch, treacle, alkalitreated straw and a mineral mixture has been successfully given to two lactating goats. A third goat was given the same diet plus a supplement of lysine.

2. Neither the yield nor the quality of the milk of any of the goats was affected by change from a normal to the experimental diet, and all three animals remained in positive nitrogen balance.

3. In the lysine-supplemented goat the milk contained slightly less lysine than the diet, whereas in each of the lysine-deficient animals, there were about $2 \cdot \mathrm{I} g$ more lysine in the milk than in the diet.

4. It is calculated that each of the two deficient goats synthesized nearly $40 \mathrm{~g}$ protein/day with the aid of its rumen symbionts. 
We are grateful to Dr E. C. Owen for suggesting the experiment and the basal diet used in it, and to Dr C. Higginbottom for growing Bacterium cadaveris. Miss S. McLaughlan and $\mathrm{Mr}$ T. Hutchison provided skilled technical assistance.

\title{
REFERENCES
}

Agrawala, I. P., Duncan, C. W. \& Huffman, C. F. (1953). F. Nutr. 49, 29.

Chanda, R., Clapham, H. M. \& Owen, E. C. (1955). Biochem. F. 60, 39 I.

Duncan, C. W., Agrawala, I. P., Huffman, C. F. \& Luecke, R. W. (I953). F. Nutr. 49, 4 I.

Gale, E. F. (1945). Biochem. F. 39, 46.

Gale, E. F. (1948). Eiweiss-Forsch. 1, 145.

Gale, E. F. \& Epps, H. M. R. (1944). Biochem. F. 38, 232.

Holmes, P., Moir, R. J. \& Underwood, E. J. (1953). Aust. F. biol. Sci. 6, 637.

Hubbell, R. B., Mendel, L. B. \& Wakeman, A. J. (1937). F. Nutr. 14, 273.

Kon, S. K. \& Porter, J. W. G. (I947-8). Nutr. Abstr. Rev. r7, 3 I.

Loosli, J. K., Williams, H. H., Thomas, W. E., Ferris, F. H. \& Maynard, L. A. (1949). Science, I10, 144.

McDonald, I. W. (1944). F. Physiol. 107, 2 I $P$.

McElroy, L. W. \& Goss, H. (1940). F. Nutr. 20, 527.

McNaught, M. L. (195I). Biochem. F. 5o, i.

McNaught, M. L. \& Smith, J. A. B. (1947-8). Nutr. Abstr. Rev. 17, 18.

Mendel, L. B. (1921). F. Franklin Inst. 192, 7.

Morris, S. \& Wright, N. C. (1933a). F. Dairy Res. 4, 177.

Morris, S. \& Wright, N. C. (1933b). F. Dairy Res. 5, I.

Owen, E. C., Smith, J. A. B. \& Wright, N. C. (I943). Biochem. F. 37, 44.

Schram, E., Dustin, J. P., Moore, S. \& Bigwood, E. J. (1953). Analyt chim. acta, 9, 49.

Smith, J. A. B. \& Baker, F. (1944). Biochem. F. 38, 496.

\section{The role of fat in the diet of rats}

\section{Influence on growth and histological findings of diets with hydrogenated arachis oil or no fat, supplemented with linoleic acid or raw skim milk, and of crude casein compared with Vitamin Test Casein}

\author{
By E. AAES-JØRGENSEN, J. P. FUNCH, P. F. ENGEL AND H. DAM \\ Department of Biochemistry and Nutrition, Polytechnic Institute, Copenhagen
}

(Received I6 April г956)

We are reporting here the results of experiments carried out in continuation of previous investigations (Aaes-Jørgensen, Engel, Funch \& Dam, 1955) into the effect of supplementing with $\mathrm{I} \mathrm{mg}$ linoleic acid/animal/day diets containing no fat or hydrogenated arachis oil. The linoleic acid is roughly equivalent to the amount of essential fatty acids consumed daily by animals reared on 'fat-free' diets containing $20 \%$ crude casein or receiving raw skim milk instead of water as drinking fluid. Another diet was prepared to contain only $0.24 \%$ arachis oil as the sole fat constituent: this quantity corresponds to the level of total fat in 'fat-free' diets containing $20 \%$ crude casein. Such a diet supplies the animals with not more than $6-10 \mathrm{mg}$ linoleic acid/animal/day. The controls were fed on diets containing $28 \%$ arachis oil. Histological studies were performed on various organs of all the animals. 